\title{
TERMS OF THE MENTAL LEXICON IN THE PROFESSIONAL AVIATION LANGUAGE TRANSLATORS
}

\author{
Halyna Yencheva \\ Ph.D., Assistant Professor, National Aviation University, Ukraine \\ e-mail: halyna.yencheva@npp.nau.edu.ua,orcid.org/0000-0003-2002-6761 \\ Tetiana Semyhinivska \\ Ph.D., Assistant Professor, National Aviation University, Ukraine \\ e-mail: tetiana.semyhinivska@npp.nau.edu.ua, orcid.org/0000-0002-6791-0397
}

\section{Summary}

The present paper establishes the possibility of presenting the mental lexicon of a technical translator in the form of a classification frame that structures the terminological composition of scientific and technical language in the translation consciousness during the cognition of aviation reality. It is stated that the terms, which are the main means of fixation, accumulation and transfer of scientific knowledge, become the object of cognitive activity of the translator, who performs cognitive work on their accumulation and structuring in their own mental space to operate them during translation, which emphasizes the heuristic nature translation activities.

At the same time, the linguistic component of the mental lexicon allows us to consider its structure, starting from the language itself. The paper attempts to present a mental lexicon within the framework of scientific and technical translation in the form of a set of frames that arrange the terminological structure of language in the mind of the translator as they learn the aviation reality. It is noted that in this case the main task is to show the possibilities of the frame in terms of accumulating and structuring the verbal knowledge about a particular aviation phenomenon or process, in English and Ukrainian with simultaneous identification of interlanguage equivalents.

Keywords: aviation terminology, translation activity, mental lexicon, classification frame, situational frame.

\section{DOI https://doi.org/10.23856/4318}

\section{Introduction}

The postulate that the language is a means of fixing and preserving the accumulated knowledge and its transfer in the scientific and technical sphere acquires a specific meaning. In scientific and technical cognition, the leading role is given to terms, which in our case are considered within the limits of their epistemological functions. S.V. Grinev identifies three functions of the term with the corresponding subgroups: fixation of knowledge (instrumental function), knowledge transfer (didactic and information functions) and the discovery of new knowledge (heuristic function). The function of fixing knowledge is that, naming the concept, the term makes it possible to manipulate it; the cognitive image becomes the subject of thought as a result of its consolidation by the corresponding term. Due to the function of knowledge transfer, the set of terms in the text allows us to get an idea of the information contained in it. Finally, the heuristic nature of terminology is created by its structural organization on the basis of semantic relations (Grinev, 1993: 218). 
All specified functions of the term are directly related to the cognitive activity of the translator, the essential point of which is the accumulation, structuring and operation of terms of scientific and technical language. Terms, which are the main means of fixation, accumulation and transfer of scientific knowledge, become the object of cognitive activity of the translator, who carries out cognitive work on their accumulation and structuring in their own mental space to operate them during translation, emphasizing the heuristic nature of translation. Considering the mental lexicon, which is often referred to as an individual thesaurus, it should be borne in mind that this area belongs to the sphere of human consciousness; therefore, any ideas expressed in this aspect are hypothetical in advance. At the same time, the linguistic component of the mental lexicon allows us to consider its structure, starting from the language itself.

Thus, within the translation of ICAO normative and technical documentation we see it possible to present a mental lexicon in the form of a set of frames that arrange the terminological structure of language in the mind of the translator as they learn the aviation reality. In this case, the main task is to show the possibilities of the frame in terms of accumulation and structuring of verbal knowledge about a particular aviation phenomenon or process in English and Ukrainian with the simultaneous identification of interlanguage correspondences.

\section{The body of the article}

Unlike the information thesaurus, which denotes a special type of dictionary, which "nominates special vocabulary within a particular information system" and "is conducted" by clarification and replenishment at certain intervals [Grinev, 1993: 255], the "individual thesaurus" of the translator is formed throughout the entire translation activity, absorbing only the most significant and correcting the available information on the arrival of new data. Such an on-going on-line process requires the translator to constantly concentrate and perform complex mental operations.

A thesaurus allows us to clearly structure the conceptual framework of a particular subject area. Under such conditions, each concept in the thesaurus has a clearly defined place in its matrix, which is determined by analyzing a group of features. The search for terms that reflect each of the concepts in the thesaurus matrix is conducted by referring to lexicographic sources or to special scientific and technical literature. Moreover, it is important to fix paradigmatic relationships in the thesaurus, that is, the relationship between concepts within a subject field.

Unlike the thesaurus, the mental lexicon is not a static but a dynamic structural formation. It is a system that is generally open to periodic replenishment and possible changes, as it actively responds to the constant development of the terminology of a particular special language. This is especially true of the Ukrainian technical language, which, compared to English, is constantly absorbing new terminology in response to the development of Western technologies.

A formal representation of such openness is possible through the use of frameworks whose hierarchical structure allows, in addition to clearly delineated vertex levels, the presence of slots that can remain empty and be filled in as information becomes available, expanding the mental vocabulary of the technical translator (Remkhe, 2007: 126).

The translator, working in the field of aviation, is undoubtedly obliged to have thesaurus knowledge, i.e. to possess the basic conceptual framework of this subject area. At the same time, the imposition of this conceptual framework on narrow situational areas leads to the identification of a number of features. In particular, it highlights the fact that the component composition of a linguistic term is usually wider than that in the thesaurus due to the higher 
level of detail and disclosure of additional features when describing a technical phenomenon in the texts of a special language.

As we know, the most productive way of replenishing lexical terms is syntactic, which implies the conversion of ordinary free words into complex "word equivalents" (Grinev, 1993: 141). The focus of attention now is on grammatical expression of the nominative and attributive nature of terminological word combinations, which is usually presented in the form of specific models of distribution of their components, which allow to distinguish the terminological word combinations from the text and fix them in a certain way.

The terminological units scope of the classification frame in the process of cognitive activity of the translator may be presented, in our opinion, based on the syntactic method of term formation, if we resort to the distribution of the component composition of terms, in the form of slots, given the specifics of communicative organization of term elements.

The concept of classification frame is chosen in the paper taking into account that intraframe classification is a necessary condition for structuring the terminological units that are part of it. The defining classifier of terminological units are certain denotative components, which indicate a particular aspect of a particular aviation phenomenon. The analysis of aviation terminology in general and ICAO terminology in particular showed that the classifier should be understood as the central slot, which is the core of the terminological phrase. It coincides in this case with the block. The lexical items that fill the slots reveal the idea of each node to the extent that it is stored in the translator's memory. In this sense, the scope of slots is individual for each translator in the field of aviation, as it is the result of his cognitive experience, reflected in the mental lexicon in the form of verbal representations.

The above-mentioned possibilities of the classification frame can be illustrated by the example of structuring the knowledge of multicomponent terms within the description of a particular concept of flight PATH, which is attached to this series of terms implicitly and explicitly is referred to as "Aircraft flight." Path (from the Latin trajectorius - one relating to movement) is a line described by a point (material body) in space during movement, the flight path (trajectory) serves as a given direction in which the aircraft flies or intends to fly (EnglishRussian-Ukrainian explanatory dictionary, 2007: 103).

In order to provide a frame representation of linguistic knowledge of the flight PATH, the authors made a comparative analysis of technical translations performed at a professional level, based on the fact that such material contains updated terminological units of a special language, represented mainly by multicomponent terminological phrases.

Multicomponent terms are known to denote a complex "object of reality" by distinct and direct focus on different sides and features (Golovin, 1987: 46). The selection of one of the features in the form of a classifier, denoting the central slot of the frame, allowed to make logic and clarity to the structuring of a particular concept of flight PATH in ICAO terminology.

In order to illustrate the "complexity" of the terminological phrases used in the language, compared to thesaurus units, we presented them on the basis of the same selected classifier, which takes the place of the central slot. Thus, Figure 1 shows the two-component terms according to the conditional scheme object+its sign, where the sign acts as a block in the flight PATH frame. In Figure 2 the highlighted sign is supplemented by a number of clarifying details, which occupy the position of prepositional slots in accordance with the specificities of term formation of the Ukrainian and English languages.

The frame representation of terminological units of aviation language allowed to state the specificities of syntactic term formation in the English and Ukrainian languages. Given the fact that the accumulation of knowledge of terminology by the translator occurs simultaneously 
within the two language systems, we consider it appropriate to present variants of classification frames in both languages in order to identify the basic patterns. For qualitative comparative analysis of terminological phrases in the working pair of the English-Ukrainian language it is necessary to take into account the communicative organization of terminological phrases.

When translated into Ukrainian, the nuclear element of the Ukrainian term occupies a central or initial place, while the dependent elements can be both prepositive and postpositive. This is due to the fact that the Ukrainian language tends to a mixed type. The Ukrainian language is characterized by two variants of the location of the nuclear element: the prepositional location of the nuclear element is observed if the dependent elements are also nouns and are joined to the nuclear element by prepositions or case inflections; the central position of the nuclear word, if one of the dependent elements is expressed by an adjective.

The multicomponent composition of terminological phrases and the inadmissibility of their literal relationship necessitate the implementation of various permutations in the translation process in order to preserve the communicative core and compliance with the norms of linguistic compatibility.

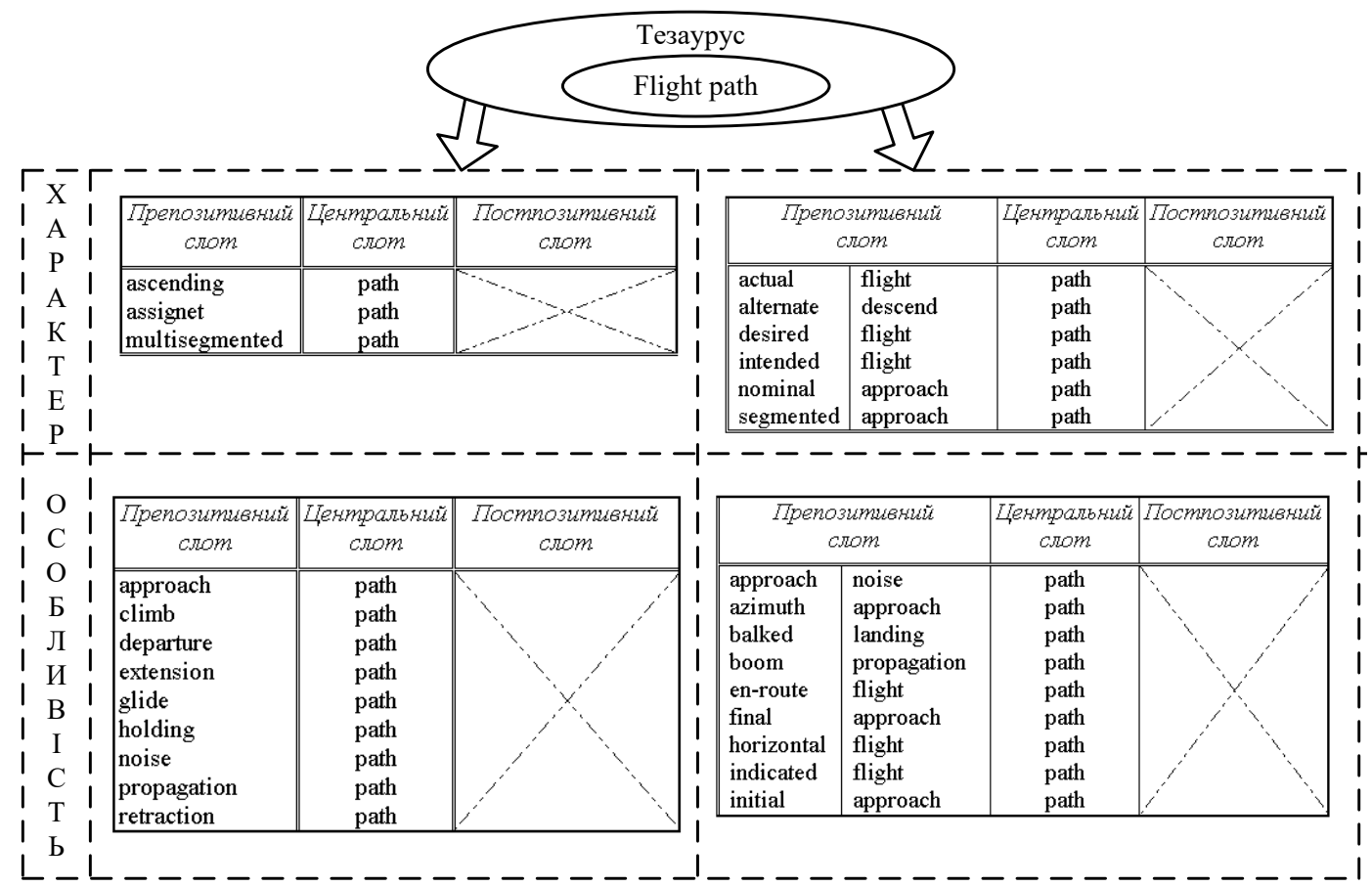

Fig. 1. Frame representation of English terms within the flight PATH concept

In general, the frame distribution of terms used in the description of the flight PATH concept is the result of the accumulation of cognitive translation experience in the aviation industry, which is considered as part of the mental lexicon of a technical translator. By schematically representing frame structures, we aim to show that the scope of the mental lexicon occurs in accordance with certain types of relations into which the terms of a special language enter. Due to the objectivity of technical language, the relations of denotative and structural character are decisive. 
In addition to intraframe, we should consider interframe relations, which include: the interaction between the classification and situational frames (background knowledge) belonging to the same thematic area; and the interaction between different classification frames, thematically related.

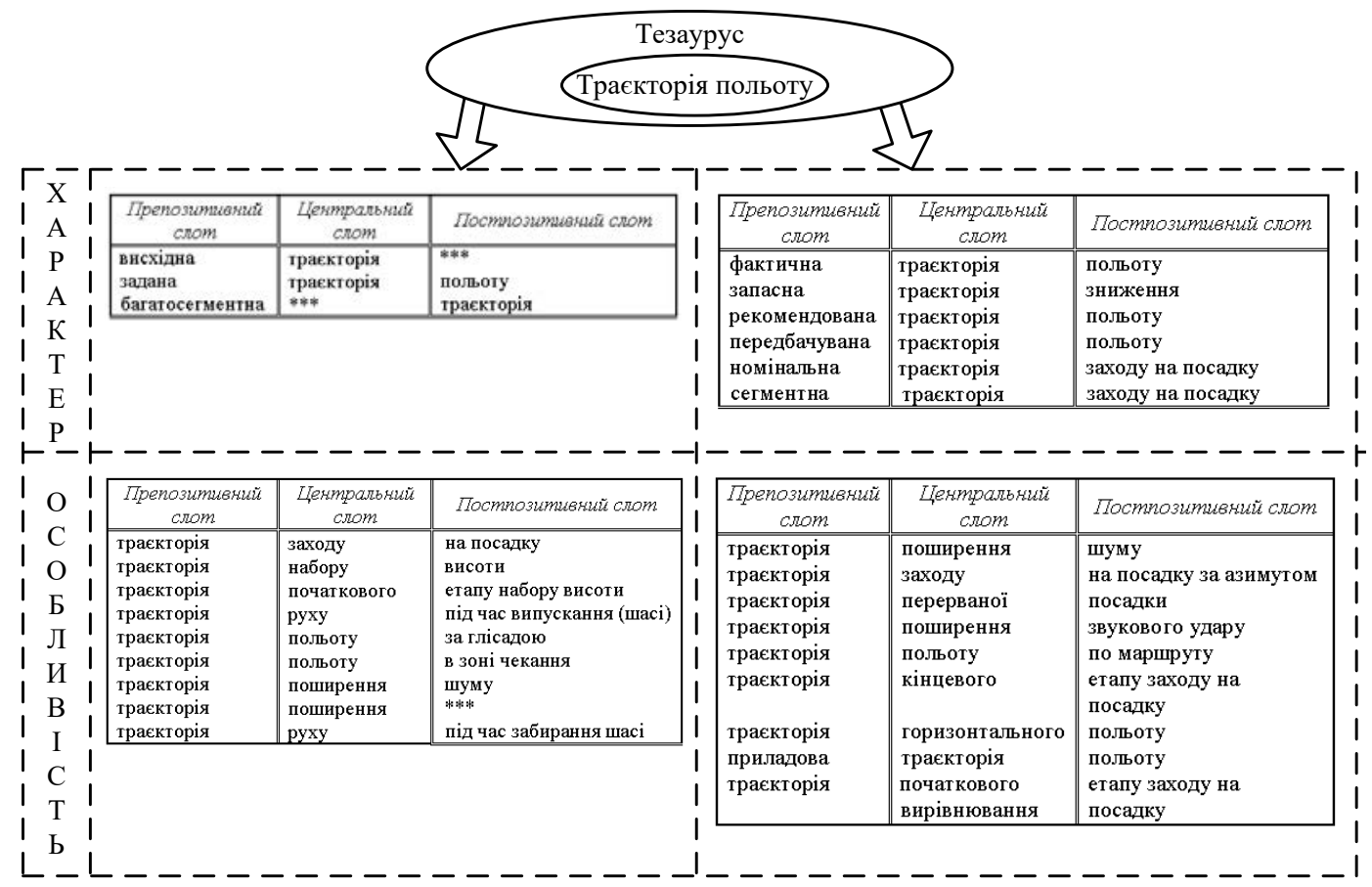

Fig. 2. Frame representation of Ukrainian terms within the flight PATH concept

The distribution of representation structures of the technical translator's knowledge into situational and classification frames is determined to some extent by the fact that terms possess two semantic aspects: ideal and visual. Ideally, technical terms contain visual images of objects of technology, their parts and technological processes. A clear example of technical terms are objects of technology, their parts and methods of manufacture (Tatarinov, 2007: 301). In this circumstance, the distribution of situational and classification frames is an important factor within the study area.

Regarding the situational frame, we believe that its content can be represented only in the form of distribution of visual information on a visual-thematic basis. A more detailed classification is unlikely, as this type of information is sought through associative connections that cannot be structured. Naturally, the memory of a technical translator contains a huge number of mental "pictures" that relate to a certain phenomenon of the surrounding reality. It is likely that this is where the process of finding translation matches in translation begins, as the translations analyzed relate mainly to the description of aviation concepts and the discussion of related issues. Therefore, when translating, an image of a technical model or various situations related to its functioning or a schematic representation involuntarily appears in the memory in the form of a drawing.

Thus, each of the vertex levels of the flight PATH frame gives an idea of the line described by the aircraft in space while moving. 


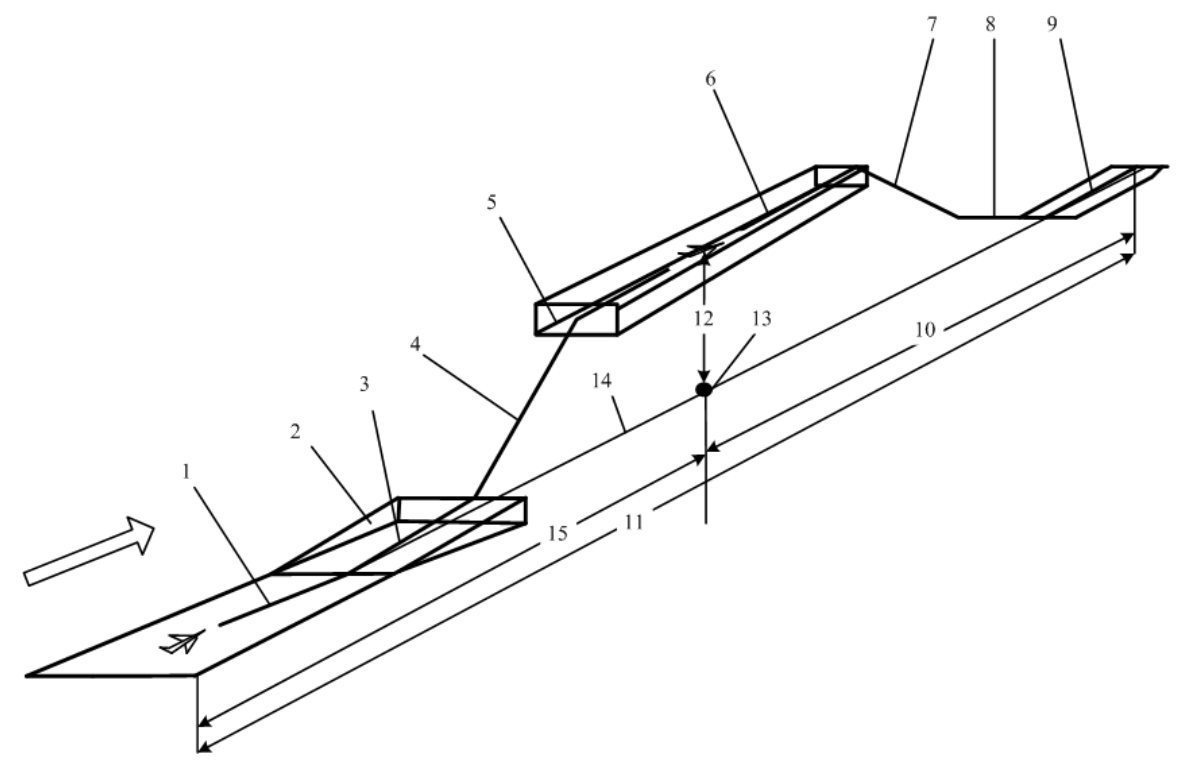

1) takeoff run - ділянка розбігу під час злітання; 2) clearway - смуга, вільна від перешкод; 3) takeoff segment - ділянка взлітання; 4) climb segment - ділянка набирання висоти; 5) flight level - ешелон польоту; 6) cruising segment - ділянка крейсерського польоту; 7) descent segment - ділянка зниження; 8) approach segment - ділянка заходження на посадку; 9) landing distance - посадкова дистанція; 10) distance to go дистанція до посадки; 11) flight distance - дистанція польоту; 12) flight altitude - висота польоту; 13) aircraft fix - місцеперебування повітряного судна (відносно землі); 14) flight profile - профіль польоту; 15) passed flight distance - пройдена частина шляху польоту.

\section{Fig. 3. Flight path of the aircraft}

Examples of the second type of interframe relationship are the correlation of frames such as "Flight speed", "Flight time", "Flight mode", "Flight profile" and "Flight altitude".

The relationship between the frames mentioned above is the match of some terminal nodes, which expands the boundaries of understanding of certain phenomena and can cause confusion or "misunderstanding" due to the shift of concepts.

\section{Conclusions}

It is worth noting that the frame distribution of the terminological system in the translator's mental lexicon represents individual fragments of the general scientific picture and allows to mentally structure a separate aviation field of knowledge. As an example, we have chosen one of the fragments that belong to the flight of the aircraft, and present the classification frames that structure the terminological units of this field of knowledge. A translator "enters" the frame through the naming unit/lexical unit or a collocation that is fixed in their mind. The nuclear position of the frame is occupied by a block sign, which contains the nuclear meaning, which is directly related to the imaginary situation. Terminal nodes/slots provide an opportunity to fill them with less vivid terminological phrases, the specification of which requires an assessment of a particular situation. 


\section{References}

Anhlo-rosiisko-ukrainskyi tlumachnyi slovnyk do MEHAmodulnoho navchalnoho kompleksu "Aeronavihatsiia" [English-Russian-Ukrainian explanatory dictionary for "Aeronavigation" MEGAModular educational complex in "Aeronavigation"] (2007) / Compiled by: Babak, V. P., Kharchenko, V. P., Zaitsev, Yu. V., K.: NAU. [in Ukrainian]

Golovin, B. N., \& Kobrin, R. Yu. (1987). Lingvisticheskie osnovy ucheniya o terminakh [Linguistic basis of the doctrine of terms]. Moskva: Vysshaya shkola. [in Russian]

Grinev, S. V. (1993) Vvedenie v terminovedenie [Introduction to Terminology Science]. Moskva: Mosk. Licej. [in Russian]

Remkhe, I. N. (2007) Kognitivnye osobennosti perevoda nauchno-tekhnicheskogo teksta (na materiale tekstov metallurgicheskoj promyshlennosti) [Cognitive features of the translation of scientific and technical text (based on the texts of the metallurgical industry)]. Extended abstract of candidate's thesis. Chelyabinsk. [in Russian]

Skorokhodko, E. F. (1963) Voprosyi perevoda angliyskoy tehnicheskoy literaturyi (perevod terminov) [Questions on translation of English technical literature (translation of terms)]. K.: Publishing house of Kiev University. [in Ukrainian]

Tatarinov V.A. (2007) Metodologiya nauchnogo perevoda: K osnovanijam teorii konvertacii [Methodology of scientific translation. To the basics of conversion theories]. M.: Moskovskij Licej. [in Russian] 